\title{
INBOORLINGENRECHT VAN DE KUST VAN GUINEA $1851^{1}$ ).
}

\author{
Regerings-Vorm.
}

De Regering is zamengesteld naar gelang der uitgestrektheic! van het krom en de onderhorige landschappen.

Te Elmina, de hoofdzetel van het Nederlandsch bestuur, in zeven kwartieren verdeeld, bestaat dezelve als volgt uit:

De Koning,

1ste, 2de en 3de Secretaris, Groot Vaandrig, Kwartiervaandrigs, Bijsonfoes en Burgemeester; terwijl voor zooverre de behandeling aangaat van zaken hun beheer betreffende, aan de Elminasche grooten zijn toegevoegd : de Koningen van Groot en Klein Commany, van Simbo en van Abremoe; de Caboceers van Ewiakrom en Doukonkrom, de Makelaar van Groot Commany, en de Caboceers van Eidiekrom en Ampenie.

Te Axim, in zes kwartieren verdeeld, is de Regering zamengesteld uit Koning, Secretaris, Spreker of Stokdrager, vijf Makelaars, Grootvaandrig, Kwartiervaandrigs en Terregenten van het boven en beneden krom.

Onder het gebied van Boutrij bestaat sedert de veroordeeling van Koning Bonsoe geen algemeen hoofd, en staan thans enkele krommen in het Ahantasche landschap op zich zelven, of meerdere krommen worden door eenen Landvoogd beheerscht. In het laatste geval heeft elk krom nog deszelfs Caboceer of kroms groote welke aan den Landvoogd ondergeschikt is. De kromsregering is verdeeld in een hoofd, kromsgrooten of oudsten en vaandrigs welke geza-

1) N.B. Dit „Verslag van Inlandsche wetten en gebruiken op Nederlandsch grondgebied ter Kuste van Guinea, opgemaakt ten gevolge slotbepaling van artikel 9 van het Reglement van bestuur aldaar" (zie Bijdr. d1. 86, 1930, blz. 33), werd opgesteld „binnen het Hoofdkasteel St. George d'Elmina” door den aldaar in 1852 overleden Lt. Kolonel Gouverneur A. van der Eb.

Op het in het Archief van het Departement van Koloniën berustend Hs. werd de aandacht gevestigd door den sedert overleden Referendaris W. H. A. van Romondt.

Redactie. 
mentlijk het bestuur uitoefenen. Het volk is verdeeld in kwartieren waarvan de Vaandrigs bepaaldelijk aanvoerders zijn. Behooren meerdere krommen onder eenen Landvoogd dan maken de bewoners van twee of meerdere krommen dikwijls slechts één kwartier uit.

Voor het regtstreeksche gebied van Boutrij bestaan vier Makelaars waarmede het Gouvernement handelt, en waaraan de bevelen, en van het volk te ontvangene diensten worden opgedragen. Van oudstijds bestaan er bovendien op verschillende strand en boschkrommen welke alhoewel onder het gebied van Boutrij behoorende, niet in de onmiddelijke nabijheid liggen, Makelaars. Op zoodanige krommen echter waar geene Makelaars bestaan wordt met de kroms grooten onderhandeld.

De Saccondecsche Regering bestaat uit den Koning, Secretaris, Makelaar en Kwartier Vaandrigs; het krom is in vier kwartieren verdeeld.

De Chamasche Regering, waaraan zijn toegevoegd de Makelaars of Hoofden van het Eiland Sepoem en Chama Iabio, telt een Koning, Secretaris, Groot Vaandrig en vier Kwartier Vaandrigs.

De Regering van Klein Cormantijn bestaat slechts uit drie personen, de Koning, Secretaris en Groot Vaandrig; die van Apam is zamengesteld uit Koning, 1ste en 2de Makelaar en twee kwartier Vaandrigs, terwijl Berkoe telt een Koning, Makelaar, drie kwartier Vaandrigs en verscheidene Bijsonfoes.

Hollandsch Accra, in vier kwartieren verdeeld, heeft een Koning, Secretaris, 1ste en 2de Makelaar, een Terregent, vier Kwartiervaandrigs en een Bijsonfoe.

Deze verschillende Regeringen zijn bevoegd tot het beslissen en afmaken van palabbers (geschil); de Koning roept voor eene zaak yan aanbelang alle zijne Makelaars, Vaandrigs en Kroms Grooten bijeen ; voor gewone zaken komen de Kroms Grooten bij den Koning ; en bij afmaking van eene zaak door de kwartieren, de Vaandrigs en diegenen welke eenigen invloed hebben.

Iemand eene zaak voor de Negerregering brengende geeft de vereischte wordende rum (minstens twee flesschen), zijne tegenpartij wordt tot dezelfde gift genoodzaakt en het geheel wordt onder elkander opgedronken en vermeerdert naar gelang de behandeling der zaak tijd vereischt. De zaken worden afgemaakt volgens bevinding en oordeel van degenen voor wien dezelve zijn gebragt; zij beraadslagen er onderling over en hooren getuigen tot staving van hetgeen partijen aanvoeren. 
Getuigen moeten alvorens tot spreken toegelaten te worden fetiche drinken; aan de bovenkust te Axim, onderanderen eisschen zij betaling voor hun compareren en verloren tijd; te Elmina en verder aan de beneden Kust wordt niets aan getuigen voldaan, en is er slechts één geval waarbij betaling voor veroorzaakte moeite te pas komt, en wel bij eene valsche beschuldiging als wanneer de gedaagde indien het eene geldelijke reclame raakt, het regt heeft om het dubbele van hetgeen onregtmatig van hem werd gevorderd te eisschen; zijne tegenpartij is daarbij verpligt alle gemaakte onkosten van Rum etc. alleen te vereffenen.

In kleine geschillen bij ontbreking van getuigen wordt door een der partijen fetiche gedronken, hij die zulks anbied of door de regering daartoe wordt gelast. Heeft de andere partij hiervoor zijne toestemming gegeven dan wordt de fetichedrinker in het gelijk gesteld.

In groote palabbers wordt tot het drinken van Edocm. (soort van kwassie = bitter) door den Koning en Grooten bevolen, en zijn zij bij de bereiling tegenwoordig. Deze drank wordt echter aan de bovenk: st niet door de in geschil zijnde partijen zelven gebruikt, maar naar gelang van hun geslacht een hunner zusters of kinderen, tot het drinken daarvan door de regering aangewezen. Te Elmina en meer beneden de Kust handelt men in soortgelijke gevallen op de volgende wijze. Er worden vanwege de regering lieden uitgezonden die buiten het krom twee geheel vreemde personen opwachten, welke zij voor den Koning brengen die hun met de in behandeling zijnde zaak en de namen der belanghebbenden bekend maakt en hun met vrijlating voor wien der partijen zij zulks doen willen, tot het drinken der Edoem gelast. Wie de Edoem drinkt en niet weder opgeeft wordt in het ongelijk gesteld en moet het gevorderde met alle gemaakte onkosten van rum en palmwijn mede voor zijne tegenpartij voldoen.

Bij het drinken van fetiche is degene welke dezelve dronk, dikwijls nog langen tijd na de behandeling eener zaak door bijzondere omstandigheden ,ernstig ziek worden etc.", hetwelk als werking of straffe der fetiche wordt beschouwd, verpligt bij deszelfs wederpartij ,slechte zaak of schuld" te komen belijden, onder aanbieding van een schaap en verzoek na vereffening, hetzij door onmiddelijke betaling of anderzints, de slechte fetiche van hem weg te nemen, opdat hij weder gezond worde.

Bij ontstaan eener groote palabber wordt door partijen gewoonlijk op de een of andere Koning, Negerhoofd, Groote of bijzondere ge-

D1. 88. 
beurtenis gezworen, waarvoor diegene op wiens hoofd zulks geschiedde geregtigd is tot den ontvangst van eene bepaalde boete welke door de in het ongelijk gestelde wordt voldaan voor zich en zijne wederpartij. Heeft hijzelven niet gezworen dan alleen voor deze.

Het zweren op het hoofd van deze of geene Caboceer of van eene fetiche, geschiedt dikwijls om zich van eene beschuldiging te zuiveren, tot het verzwijgen van eene gepleegde misdaad of tot het ten uitvoer brengen van iets dergelijks. Ook heeft het zweren op de Cabes somtijds plaats om door anderen daden ten uitvoer te doen brengen, waardoor dezen niet zelden zelven in groote palabbers worden gewikkeld.

Bij gevecht of voor zij oorlog aangaan wordt eerst de groote kromfetiche geraadpleegd door het trekken der acht fetiche touwtjes, en deze bij aldien zij gelukkig zijn een schaap beloofd; niemand trekt ten oorlog zonder buitendien beloften aan zijne bijzondere huisfetiche te doen.

Elk man welke het geweer dragen kan is tot verdediging van het land of krom verpligt. De vaandrigs zijn hunne onmiddelijke aanvoerders die de plannen tot aanval etc. regelen, en aan wien zij onvoorwaarlijk gehoorzaamheid verschuldigd zijn.

Elke vreemdeling is verpligt met het kwartier waarin hij zich eenigen tijd ophield uit te trekken; hij wordt van kruid en lood voorzien, en de onkosten daarvan onderling of door de Caboceers of Grooten gedragen. Die zich aan den oorlog onttrekt heeft dikwijls straffen, en stellig verwijtingen van de vrouwen te wachten. Oude lieden en vrouwen worden gebezigd tot het dragen van amunitie; zij maken de achterhoede uit en zijn onder toezigt van de kromsGrooten die het kruid en lood uitdeelen, en over de kansen der oorlog beraadslagen.

De gevangen vijand wordt meestal onmiddelijk onthoofd, en vrouwen en kinderen bij verovering van een krom weggevoerd en later als slaven verkocht. Kwartieren van een krom onderling palabber hebbende, en tot gevecht komende, worden de gevangenen gewoonlijk tegen losgeld vrij gegeven.

\section{Verpligting en Verhouding van het Volk jegens de Landvoogden en Kroms-Grooten.}

Alhoewel elk inlander, geen slaaf zijnde, over zichzelven beschikt, oefenen de Kroms Grooten een aanzienlijke magt uit, en zijn het vooral de Vaandrigs waaraan het volk het meeste gehoor geeft.

Het Gouvernement, volk tot dragers of ander werk benoodigd 
zijnde, geven de Vaandrigs gezamentlijk met de Makelaars hunne bevelen. Ieder op zijn beurt wordt tot werk gelast, en hij die zich daaraan onttrekt of verzuim laat blijken, met rietslagen of eene kleine boete gestraft. Vreemdelingen tijdelijk het krom bewonende, zijn van bovenstaande maatregel niet uitgesloten.

Uitgenomen enkele boeten voor kleine misdrijven welke door de Kroms Grooten worden afgemaakt, heeft het volk hoegenaamd aan hen geene lasten of regten te betalen. Wordt soms een krom of kwartier door het Gouvernement beboet, dan draagt elk inwoner of diegene welke tot het Kwartier behoort deszelfs deel bij.

\section{Tijd Rekening.}

De tijd wordt berekend bij manen of maanschijn. Iedere maan dertig dagen, twaalf manen een jaar, eene maan vier weken en eene week zeven dagen; zoodat iedere maan eene maand uitmaakt, en bij eene hernieuwde verschijning eene nieuwe maand voor hun aanvang neemt.

Bij overle:ering hunner voorouders hebben zij eene instelling welke de wek: verdeeld in goede: Adei, half slechte: Adim en ongelukkige: Ayanfco; iec?ere dag der week te beginnen met Adei (Zondag) wordt eene dezer benamingen toegevoegd, de volgende Zondag Adim, de derde Ayanfoo en de vierde weder Adei. Zij verdeelen wijders de dagen der week in mannen en vrouwen of gelukkige en ongelukkige dagen; Zondag, Woensdag en Vrijdag zijn de gelukkige of mannendagen, waarop zij hunne ondernemingen regelen, costuum maken en te velde trekken.

\section{Landbouw, Rosaren, Etc.}

Ieder inlander heeft deszelfs eigen of familiegrond in, ook buiten het krom, of onder andere krommen gelegen. $\mathrm{Hij}$ en de zijnen alleen mogen er werken, zij rosaren eenmaal 's jaars en maken den grond tot beplanten geschikt.

Wanneer iemand zonder zijn toestemming van den grond gebruik heeft gemaakt, dan neemt de eigenaar eene pot en zet dezen ten ondersten boven op zijn eigendom, ten teeken niemand aldaar gedurende drie jaren zal mogen rosaren. $\mathrm{Na}$ verloop dezer drie jaren wordt er ter plaatse eene kabriet geslagt en met haar bloed de pot besprengd, waardoor de fetiche is opgeheven; zoolang zulks niet is geschied, moet volgens algemeen geloof alle oogst op den geschonden grond mislukken. 
Ieder krom of gehucht heeft eene grond of boschfetiche volgens welke aldaar eenen dag in de week niet gewerkt mag worden. Aan de bovenkust wordt daarenboven elke Adim maandag en elke vrijdag niet gerosaard; te Elmina en verder benedenwaarts de Kust gaan dingsdags geene visschers uit, en wordt in het bosch niet gewerkt.

\section{Slavernij.}

Slaven zijn het volstrekt eigendom van hunne meesters en kunnen weder door hun worden verkocht, met uitzondering van familieslaven, welke door bijzondere bepalingen aan het familiehuis of den stoel behooren. Men verkrijgt slaven door aankoop, erfenis of gevangenneming in tijd van oorlog. Slavinnen kinderen worden het eigendom van haren meester, zelfs dan wanneer de Vader een vrije neger is. Slaven worden door den eigenaar onderhouden, tenzij deze hun vergund voor zichzelven te werken, hetgeen somtijds plaats heeft met verarmde familien.

\section{Impia of Pandelingschap.}

Iemand kan door deszelfs familie als pand worden gesteld, of zich zelf voor schuld als dusdanig geven. De pandeling is voor den tijd zijner impiaschap als slaaf van den pandhouder te beschouwen, met die uitzondering dat hij niet kan worden verkocht. Hij is verpligt het hem opgedragen werk te verrigten en geniet daarvoor voeding en kleeding.

Het stellen eener impia is zeer algemeen en wordt gehouden voor eene gemakkelijke leening zonder of met bijbetaling van minder interessen dan bij eene gewone leening, waarvoor $50 \%$ rente wordt in rekening gebragt.

Wanneer de impia eene vrouw heeft of neemt, werkt hij slechts drie dagen in de week voor zijnen meester, welke hem de overige dagen geeft om voor zich en de zijnen te werken; in dat geval bekoomt de pandeling dan ook slechts met het nieuwjaars-feest of Kontoem eenige paantjes en wat rum of palm-wijn ten geschenke. Een impia als boodschapper of andersints door zijnen meester naar elders gezonden wordende ontvangt goud tot onderhoud voor de reis.

Wanneer zulks bij de gemaakte overeenkomst niet is verboden, wordt de vrouw voor impia gesteld, veelal als vrouw genomen; zij zorgt in dat geval voor de huishouding en persoon haars meesters, en de gewone interest van eene dollar voor ieder geleend once goud wordt bij de restitutie niet gerekend. 
Wie impia moet stellen om zijne schulden te voldoen, beschikt over deszelfs vrouw, kinderen en slaven, ook over impia's reeds door een ander bij hem gesteld. Het hoofd eener familie, op den stoel dezer familie geplaatst, over alle derzelver jongere leden, deszelfs broeders en zusters of hunne nakomelingen, welke hij weder aflost, zoodra zijne middelen zulks gedogen.

Het goud voor de impia wordt gewogen met $1 / 16$ Engels of een smanka doorslag; bij de teruggave van het goud is het dubbele der gewogen doorslag verschuldigd, en men betaalt bovendien een Engels voor ieder geleend once.

Wanneer de impia weigert te werken of wegloopt, is men verpligt een ander persoon in zijne plaats te stellen, of het geleende goud terug te geven, met bijvoeging van alle onkosten wegens opsporing of terugbrenging van den impia gemaakt door degene bij wien hij was gesteld.

De impia zich in schulden brengende, en deze door den pandhouder betaald wordende, komt het bedrag daarvan geheel of gedeeltelijk na overeenkomst met degene die hem voor impia stelde, ten laste van de hoofdsom.

Wanneer de impia komt te overlijden, en verre van degene verwijderd is die hem stelde, of het vervoer derwaarts moeijelijk is, wordt hij door deszelfs meester begraven, welke de onkosten geheel of ten deele in rekening brengt naar gelang hij over den impia te vred nn was of niet. Hij zendt eenen boodschapper tot den steller der impia om van het overlijden berigt te geven en verzoekt om te komen rekenen; waarna de geleende som wordt teruggegeven of eene andere impia gesteld.

Bij overlijden der impia is steeds een derde der geleende som verloren, en wordt dit van het geheel afgetrokken, zoodra het verschuldigde bedrag is gebleken.

Een Caboceer veel goud benoodigd zijnde, stelt zich zijn volk en krom voor impia, en gaat wekelijksch met zijne onderhorigen naar gelang der overeenkomst voor den geldschieter, twee à drie dagen rosaren tot zoolang de voorgeschotene gelden zijn vergoed.

$\mathrm{Bij}$ het stellen van fetiche of sieraad, goud en goederen voor impia wordt de tijd tot aflossing bepaald; is deze met een klein uitstel, wat steeds wordt toegestaan, verstreken dan heeft de pandhouder het regt het goud etc te verkoopen of voor zich te behouden, tegen de prijs waarvoor hetzelve werd gesteld, zonder daardoor deszelfs regt te verliezen op het meerdere bedrag der schuld in vergelijk der waarde van de verkochte of verbeurticrklaarde impia. 


\section{Verdeeling der Stammen.}

Met een gering onderscheid is de verdeeling der verschillende stammen langs de Kust van Axim tot Accra als volgt:

1. Entjua, de honden.

2. Ensonna, de vossen.

3. Ekkoena, naam van den oudsten der stam.

4. Arvowin, slakkenhuizen.

5. Djumna, naam van den oudsten der stam.

Deze vijf stammen behooren bij elkander.

6. Annona, de papagaaijen of Annos kleine kinderen.

7. Afiënna, naam van den oudsten der stam.

8. Agonna, naam van den oudsten der stam.

Deze drie stammen behooren bij elkancler.

9. Sakkio, naam van den oudsten der stam.

10. Akkona, de buffels.

11. Abrotoe, de melhiostruiken.

12. Eibriadie, de geheimlieden.

13. Etjudan, de tijgers.

14. Agonnie, de koralen.

Deze zes stammen behooren bij elkander.

\section{Godsdienst, Fetiches.}

Hoewel het geloof aan een Opperwezen Lij sommige Inlanders bestaat, neigt het algemeen naar eene goede en slechte fetiche; of naar eene goede of slechte Saman of geest. Elke fetiche heeft zijnen bijzonderen naam, zoowel de groote krom fetiches, als de zoogenaamde huisfetiches.

De goede fetiches worden gezegd te verblijven op alle eenzame plaatsen, eilandjes, groote rotsen of zoodanige plaatsen als door de fetiche priesters worden aangewezen. $\mathrm{Zi}_{\mathrm{j}}$ weten nict wat eigenlijk hunne fetiches zijn, hebben echter voor de plaatsen aan dezelve gewijd veel vrees en ontzag; verbeelden zich iedere fetiche hun naar welgevallen doet leven of sterven, ziek of gezond maakt, in alles behulpzaam kan zijn, en over hun naar goeddunken beschikt, waarom zij door hunne offers trachten dezelve ten goede te stemmen.

Het verblijf der slechte fetiches is onbekend; men veronderstelt dat zij zich in het bosch en in den grond ophouden.

Door Saman wordt verstaan: de goede of slechte geest van eenen overledene, wanneer door ziekte of vele volgende sterfugtvallen in 
eene familie blijkt dat dezelve slecht is, hetgeen de fetiche priesters en touwtjes moeten beslissen, wordt een zoodanig lijk opgegraven en verbrand; hierdoor de slechte Saman vernietigd en van de familie van den overledene de ziekten etc. aan den Saman toegeschreven, weggenomen.

De goede fetiches zijn verdeeld in algemeene en bijzondere; de algemeene zijn die waarvan slechts één in ieder krom is, en door hen de groote fetiche genaamd wordt, aan wien voor het algemeen belang, voor goede vischvangst, goede oogst, voor regen en droogte wordt geofferd.

De bijzondere of huisfetiche is die van elken neger voor zich en zijn huisgezin; zij offeren aan deze bij iedere buitengewone en goede gebeurtenis. De offers bestaan gewoonlijk in vleesch van boschkabrieten, pisang, jams en eije:en; het bloed en de ingewanden van schapen en kippen wordt in de fetische bak gestort, welke zich veelal in de slaapkamer bevindt. Wanneer hun iets bijzonders overkomt raadplegen zij de fetiche of laten hiervoor eenen fetichen priester roepen, welke met behulp van de fetiche trom en touwtjes verklaart wat de fetiche wil, welke offers hij verlangt, en bij ziekte wat er gedaan moet worden om te herstellen. Aan de slechte fetiches moet het geheele offer gegeven worden, aan de goede alleen het bloed en de ingewanden; somtijds een der voorpoten van het gedoo.'? dier.

meeste der Negers dragen een stukje goud ter eere hunner bijzondere fetiche; die vele slaven bezit heeft gewoonlijk een derzelven naar zijne fetiche genaamd, welke alsdar: ook ter eere van deze fetiche een stuk fetiche om den hals draagt.

Ieder Negar heeft voor zijn leven ene verboden spijs of drank; eenige mogen b.v. geen palmwijn drinken, andere geene kabrieten of k.jpen eten, derden alleen kippen grebruiken die van zuiver witte vedere:s voorzien zijn. Ook heeft 'der eenen dag in de week de dag zijner fetiche, waarop hij guen kaantje (milie brood), geen kabrie of krabben mag eten, geen palmwijn mag drinken. Iedere fetiche heeft zijne soort van verbodene spijs of drank.

Vooi, de goede Saman wordt ieder jaar bij het eten van nieuwjams een schaap en rum geofferd. Om te weten of dit offer goed en aangenaam is wordt eerst een haan slagt, en zijn de in dezen gevonden zaadballen zwart dan bestaat $\mathrm{e}$ : eene hindernis, en worden de fetiche touwtjes geraadpleegd on te veten welke deze is, en haar weg te nemen, waarna men eenen tw :aden haan slagt en daarmede 
voortgaat tot dat er een is aangetroffen, waarin beide genoemde deelen geheel wit zijn.

De acht fetiche touwtjes zijn stukken touw of leder waaraan in het midden verschillende zaken, als eene tijgertand, een stukje ijzer of koper, de poten van een boschkabriet, van den miereneter etc. zijn bevestigd, en welke weer afzonderlijk verschillende beteekenissen hebben. Deze touwtjes worden door een persoon hieraan gewoon door elkander getrokken, en zooals het toeval of de behendigheid dezelve te zamenbrengt, de beteekenis er van uitgelegd in overeenstemming met hetgeen men wenscht te vernemen.

\section{Fetiche Pricsters \& Pricsteressen.}

Het priesterschap bestaat op weinige uitzonderingen na niet door erfregt; elk een deze waardigheid kunnende bekleeden en weder verlaten, aanvaarden vele dezelve ter bereiking van een gemakkelijk en lui leven. Die voor de betrekking genegen is, en zich daartoe aanbiedt, gaat voor een tijd bij een fetiche priester in de leer, wordt door hem met de geheimen van het vak bekend gemaakt en daarna openlijk ingewijd.

Hoewel de fetiche priesters geen direct deel aan de regering nemen wordt er geene groote zaak beslist, geen oorlog ondernomen zonder hun te raadplegen. Algemeen staan zij in groote achting, en wordt soms een fetiche priester door Europeesche gezagvoerders gearresteerd, het volk zal zich veele moeite en opoffering getroosten. om hem zijn vrijheid terug te geven.

Meestal met de kracht en de werking van inlandsche gewassen (medicijnen) bekent, worden zij als docters gebruikt, en aangezien zij zich goed laten betalen, zijn hunne inkomsten niet, gering.

Eene vrouw welke verklaart de ingeving als fetich priesteres te hebben ontvangen, wordt indien zij gecalesaard is door haren man vrij gegeven, en even als hiervoren gezegd is, in de leer gezonden.

De priester Antona bestaat door erfregt en wordt opgevolgd door de nakomelingen van den persoon Oddena, een jager van Simbo die het eerst Elmina ontdekte, en zich met zekeren Acramanca van Cape Coast vereenigde ter oprigting van eene hut op de plaats welke nader den naam van Kapel heeft verkregen.

$\mathrm{Na}$ den dood van deze twee lieden hebben hunne kinderen en kindskinderen andere hutten opgezet; de muts en het trommeltje waarmede zich hunne ouders vermaakt hadden, even als hunne woning, voor heiligdommen gehouden, en een hunner tot priester 
gemaakt. Uit dien hoofde heeft de priester Antona het regt, om op zijne heilige dagen alles wat hij, hetzij van producten of vee tot het doen van offers noodig heeft, door zijne dienaren op de markten te laten wegnemen.

Het was met Acramanca en zijne onderhorigen dat Diego d'Azambaja in het jaar 1482 overeenkwam om het Fort St. George te Elmina te bouwen; hetzelve werd in 1637 op last van Graaf Mauritz van Nassau door de Hollanders veroverd, onder bevel van den Overste Kuhn met eene sterkte van negen schepen, acht honderd Militairen en twee honderd Matrozen.

Nogthans leest men voor het Fort te Elmina in de latijnsche taal het volgende:

Toen de doorluchtigste en edelmoedigste J. Mauritz, Graaf van Nassau, Braziliën beheerschte, is onder het opperbevel van den Overste Kuhn dit zeer sterke slot in vier dagen bemagtigd en ingenomen in het jaar 1637 den 29en Augustus.

$$
\text { Afgoden of Fetiches. }
$$

Iedere landstreek heeft zijne fetiches of goden; behalve de Antona, eene rots, en de Iatar, eene kom te Elmina, bestaan hoofdzakelijk de volgende :

Benjan eene rivier te Elmina, Bossumpra eene rivier te Chama. Bossum Etju eene rivier te Astrantijn, Tando eene rivier te Astrantijn, Sakkoem eene rivier te Acra, Emisang eene rivier in het Tontijnsche, Greboerra eene kom te Affoetoe, Aasmankma eene Boschkaadje te Eqoeafoe, Bossum-Doem, eene Edoemboom op de Eqoeafoesche berg.

De zon, maan en sterren worden over de massa genomen, geene eerbied bewezen. Kwartier twee van Elmina laat bij nieuwe maan drie malen hare fetiche trommen slaan, en bij iedere slag wordt een verbazend leven en geschreeuw gemaakt.

\section{Fetische Becsten,}

zijn de Olijphant, de tijger, het ram, de landschildpad, de krokodil. de leguaan, de hagedis, de zwarte slangen, de stinkvogel, de valk, de papagaai, de walvisch en meer anderen.

$$
\text { Fetische Meiden of openbare Vrouwen. }
$$

Vooral in het Ahantasche landschap vindt men deze schepsels. Het zijn meestal slavinnen of slavinnenkinderen, welke door vermogende 
mannen of vrouwen bepaaldelijk hiertoe worden aangekocht, of van jongs af bestemd en aan het publiek geschonken. Door kleeding en opschik zijn zij voor iedereen te herkennen, en worden door de fetiche priesters of priesteressen zoodra zij huwbaar zijn, met bijzondere ceremoniën ingewijd. Zij staan elk man tegen betaling van 1/12 Engels goud ten dienste, op uitzondering van hem die hen na de inwijding het eerst beslaapt; deze vervalt in een te betalen kostuum hetwelk wordt besteed ter aankoop van nieuwe voor het vak bestemde meisjes.

Van het verdiende loon moet meestal nog ten behoeve der eigenaars of eigenaressen worden afgestaan. $\mathrm{Er}$ is geene bepaling die de dochters verpligt om het bedrijf der moeder uit te oefenen; meestal heeft zulks geen plaats.

\section{Ajins of Vampijrs.}

Het geloof aan Ajins is zeer algemeen en dikwijls hebben beschuldigingen plaats tegen personen welke hiervoor worden aangezien. Men schrijft hen de magt toe, om in de slaap onmerkbaar te dooden, het bloed uit te zuigen of andere onheilen te weeg te brengen. Menschen als Ajins beschouwd worden door het volk verafschuwd, en hebben menig maal mishandelingen te verduren; vroeger werden zij levend verbrand, thans echter wordt hun Edoem toegediend, en daarbij even als bij beschuldiging van groote misdaden plaats heeft, de „Eed van Zuivering" toepasselijk gemaakt.

Deze eed bestaat in het aanroepen der fetiche, welke hun wanneer zij de waarheid te kort doen mogen dooden, of bij het heiligste voor den Neger de nagedachtenis en het gebeente van hunne voorouders. welke zij de grootste achting toedragen.

\section{Vrouwen Schennis.}

Hoewel deze misdaad, welke zelden voorkomt, door de Negers niet van zeer groot belang wordt gerekend, laten dezelve het misdrijf niet ongestraft.

Door de kromsgrooten eene dusdanige zaak afgemaakt wordende, vervalt de dader in eene geldboete van 1 once à 4 once Engels liquide goud ten hehoeve van de vrouw zelve, of van de moeder van het meisje waaraan het misdrijf werd gepleegd.

Een man en eene vrouw buiten het krom in de opene lucht gemeenschap met elkander hebbende, worden beide in eene kleine boete geslagen, en algemeen door het volk openbaar uitgejouwd. 


\section{Huwelijk-Calisaren. \\ Verpligting van de Vrouze omtrent den Man.}

Het huwelijk geschiedt zonder toestemming van het meisje, en wordt door de ouders en wel hoofdzakelijk door de moeder geregeld. Het kostuum is onbepaald; gewoonlijk wordt er 1 once goud met wat rum, tabak en paangoederen aan de familie betaald. Is het costuum betaald dan wordt het meisje openlijk rondgeleid, en door de familie en vriendinnen bij den man te huis gebragt, ten einde ieder te doen weten dat zij van dat tijdstip af zijne wettige vrouw is.

Een vader is verpligt ieder zijner zoonen eene vrouw te geven en het hoofdgeld voor hun te voldoen; zoolang hij zulks niet heeft gedaan is hij aansprakelijk voor alle boeten of costumen wegens overspel op de zoons loopende.

Ieder calisaart zoovele vrouwen als hij onderhouden kan en hem goeddunkt; zij brengen niets ten huwelijk, er bestaat geene gemeenschap van goederen; de man is verpligt zijne vrouw alle benoodigheden te geven, alle aankoopen voor de huishouding te doen, en zijne vrouw goud voor dezelve te geven.

De vrouw zorgt dat de spijzen worden toebereid en doet geene negotie dan ten voordeele of namens haren man. Manspersonen, behalve die harer familie, haar geschenken doende komen deze aan den man. De vrouw tijdens haar huwelijk in schulden komende wordt hare familie hiervan kennis gegeven, en de man betaalt geheel of gedeeltelijk ten laste van de familie; ook de vader of een der leden van de naastbestaanden van zijne vrouw kunnen voor schulden zich bij den man om goud vervoegen; hij verstrekt zulks naar goedvinden en voegt het geleende bedrag bij dat van het voor de vrouw betaalde hoofdgeld.

De man kan voor zijne schulden vrouw en kinderen als impia's stellen, doch is verpligt bij de aflossing alle schulden door hun gedurende het impiaschap gemaakt te voldoen, zonder zich deswege op de naastbestaanden van de vrouw te kunnen verhalen. De vrouw gedurende haar impiaschap kinderen bij eenen anderen man verwekt hebbende, brengt deze bij de aflossing tot haren man, die dezelve als de zijnen aanmerkt, en over hun na welgevallen beschikt.

Een man zonder het vereischt wordende costuum te betalen, met eene vrouw verblijvende, kan haar nog de bij haar verwekte kinderen als impia's stellen; hij onderhoudt en kleedt hen, zij werken voor hem. De vrouw hare broeders of zusters, en zusters nakomelingen kumnen 
zoodanig verwekte kinderen als impia's stellen; de vader of deszelfs opvolgers zijn van dit regt ontstoken.

Man en vrouw verlaten elkander na goedvinden; hetzij de man de vrouw wegzendt of vrijgeeft, of zij verklaart niet langer bij hem te willen blijven.

Wanneer de man de vrouw voor overspel of andere gegronde redenen wegzendt, eischt hij van de familie het betaalde costuum, de voor haar of voor de hare voldane schulden, en tien dollars hoofdgeld voor ieder der bij haar verwekte kinderen. De vrouw is verpligt alle goederen, goud en paantjes gedurende het huwelijk van haren man verkregen terug te geven; de kinderen bij den vader willende blijven, worden twee dollars voor ieder hunner van het bedrag door de vrouw en hare familie aan den man verschuldigd afgetrokken, en de tien dollars hoofdgeld niet berekend.

Wanneer het huwelijk met wederkeerig goedvinden wordt ontbonden dan eischt de man steeds dat de vrouw door het drinken van fetiche bezweert dat zij hem nimmer ontrouw was of dit beleed. Verkiest de vrouw te scheiden en veronderstelt de man dat zij met iemand anders wil gaan leven dan verklaart hij haar onder het drinken van fetiche en noemen van persoon, dat indien zij dezen tot vrouw koomt. de fetiche haar zal dooden. Wil nu de vrouw werkelijk later met eenen zoodanigen persoon eene verbintenis aangaan, dan is zij verpligt haren vorigen man eerst te verzoeken de bezwering van haar weg te nemen, hetgeen meestal geschiedt tegen betaling van 4 Eng. liq. goud.

Een man, lange jaren met eene vrouw verblijvende, bijzonder over haar tevreden zijnde, en haar dit willende bewijzen, roept hare familie bij elkander en verklaart haar het hoofdgeld te schenken, en dit nimmer, in welk geval ook, te zullen vorderen. Ten bewijze van dankbaarheid zendt de familie, na deze verklaring den man een schaap en eene flesch rum als geschenk.

Zooals reeds gezegd is de vrouw zorgt voor het huishouden; wordt de man tijdens hunne verbintenis behoeftig dan is zij wanneer er geene andere middelen daartoe bestaan, verpligt in zijne voeding te voorzien.

Bij overlijden van den man worden tien dollars van het betaalde hoofdgeld aan de vrouw geschonken, wordt zij door deszelfs opvolger als wettige vrouw aangenomen en voldoet deze slechts een en een half Engels liq. goud als nieuw hoofdgeld aan de familie. In zulke gevallen behoudt de vrouw alle goederen van haren eersten man, en tijdens haar vorig huwelijk verkregen. Wanneer zij niet bij den opvolger van haren man wil blijven, wordt het hetaalde costuum, het 
hoofdgeld der kinderen, de voor de vrouw met weten harer familie betaalde gelden en alle paantjes en gouden sierraden terug genomen.

Ook bij overlijden der vrouw vervallen tien dollars van het voor haar betaalde costuum, en willen de kinderen bij den Vader verblijven dan wordt het bedoelde bedrag geheel geschonken; hare paantjes en sieraden worden gedeeltelijk met haar begraven, en onder de kinderen verdeeld. Zijn er geene kinderen dan wordt alles door den man behouden, en het hoofdgeld en de met weten der familie voor de vrouw betaalde schulden gerestitueerd.

\section{Ouderlijk Regt op de Kinderen.}

Elk kind van vrije negers is het eigendom van zijne ouders, kan door hun als pand worden gesteld, en als slaaf worden verkocht. Daar bepaaldelijk de moederlijke linie wordt gevolgd, oefent de moeder het grootste gezag over de kinderen uit. Het kind is verpligt voor deszelfs ouders te werken, en wordt zoolang tot dat hetzelve in staat is voor eigen onderhoud te zorgen, door hen gevoed. Zusters kinderen, waarvan de ouders overlijden, worden insgelijks het eigendom van den oom of tante van de moeders zijde, en ontvangen dezen dan ook den naam van vader en moeder. Ditzelfde heeft plaats met verdere betrekkingen, welke aan de erfgenamen van de moederszijcle vervallen.

Alhoewel de kinderen de moederzijde volgen, trekken de zonen met het Kwartier van den vader te velde.

\section{Onderlinge Verpligting der Familien.}

Bij belangrijke zaken bestaat eene familieraad, welke over de betaling van zekere schulden, en over de regeling van andere zaken de familie betreffende handelt. De familie helpt elkander onderling bij het bouwen van woningen en het bewerken van land.

\section{Familie Schulden.}

Elke erfgenaam welke de erfenị heeft aanvaard, is verpligt wanneer er door belanghebbenden aangifte van een door den erflater nagelaten schuld is gedaan, dezelve te voldoen. Deze aangifte geschiedt met het geven van een à twee flesschen rum. De aangifte verzuimd zijnde, kan de betaling worden geweigerd, tenzij er voldoende getuigen bestaan, of de eischer bij het overlijden van den erflater is afwezig geweest.

Verouderde erkende familieschulden worden door het hoofd der 
familie of door de gezamentlijke leden gedragen. Gewoonlijk helpt zich eene zoodanige familie, wanneer er geen geld voorhanden is, met het pandstellen van een of meerdere der betrokkenen. De ouders kunnen voor de schulden van hunne kinderen, zoolang 'zij bij hen inwonen, worden aangesproken.

\section{Personele Schulden.}

Iedere schuldenaar zijne schulden niet betalende kan hiervoor worden aangeklaagt, hetzij bij het Gouvernement of bij de Kroms Grooten. De aangifte van de vordering geschiedt bij de laatste met vooruitbetaling van een weinig rum waarvan de onkosten op rekening van den schuldenaar komen. Gewoonlijk wordt een klein uitstel voor de betaling verleend; is dit verstreken 'en de vereffening niet geschied dan wordt de schuldenaar aan een blok geslagen tot de betaling volgt.

(Deze maatregel is sedert lang door het Gouvernement krachtdadig tegen gegaan en vindt thans zelden plaats daar waar een Europeaan bevel voert).

De schuld ontkent wordende wijzen getuigen of de Edoemdrank de kwestie uit.

Geene schulden hoegenaamd mogen worden gevraagd op den fetichen dag of gedurende de kontoem. Iemand zich voor schulden verwijderd hebbende kan zich op dezen tijd, met zekerheid voor zijnen persoon, vertoonen.

\section{Ziekten. - Besmetting.}

Bij verschijning eener aanstekende ziekte wordt aan den ingang van het Krom op de algemeene weg eene boschkabriet aan drie stokken opgehangen, een kabriet uit het Krom in den omtrek begraven, stokken regt in den grond gestoken en tusschen deze weer andere ingevlochten en met klei vast gezet. Op de groote fetiche plaatsen van het Krom wordt rum, palmwijn en een schaap geoffert, de kontoem trom geslagen en gedurende den dag de kontoem dans gedanst.

Men is verpligt diegenen welke door eene besmettelijke ziekte wordt aangetast, onmiddelijk uit het Krom te verwijderen, en op eene afgezonderde plaats in het bosch te behouden. De zieken worden zooveel mogelijk alleen door personen opgepast, die vroeger aan dezelfde kwaal lijdende waren.

Bij ziekte worden de fetiche priesters steeds geraadpleegd, zoowel 
om 'bij de fetiche naar de oorzaak der ziekte te vernemen, als om die weg te nemen en de zieke van geneesmiddelen te voorzien.

\section{Gebruiken bij de maandelijksche Zuivering en Zwangerschap der Vrouz.}

Gedurende de maandelijksche zuivering is de vrouw onrein, en leeft zes dagen alleen zonder de woning van haren man te mogen betreden. In de boschkrommen wordt dit gebruik het stipste opgevolgd, en begeeft zich de vrouw gedurende den bedoelden tijd buiten het krom.

Een meisje huwbaar zijnde wordt dit door versieren en rondleiden bekend gemaakt, en mag zij gedurende acht dagen geen huiselijk werk verrigten.

Te Accra alleen hebben in dit geval geene openlijke costumen plaats, de familie wordt slechts met den maagdelijken staat bekend gemaakt.

Bij de eerste zwangerschap der vrouw wordt zij tegen de achtste maand door eenige vriendinnen met fetiches omhangen, met aarde klei en ander vuilnis besmeerd en naar zee gebragt, om te worden gewasschen. Op haar togt derwaarts heeft zij echter te verduren dat de jongens haar met steenen enz. werpen tot de plegtigheid is afgeloopen.

Eene vrouw gedurende de zwangerschap stervende wordt geopend, het kind uit het ligchaam gehaald, en bij de moeder begraven. Te Accra wordt eene zoodanige overledene vrouw niet ter aarde becteld. maar naar het bosch gedragen, en ten prooi aan de dieren des velds gelaten.

Een miskraam wordt de vrouw als schande aangerekend en heeft dit plaats dan wordt zij door het jonge volk en de vrouwen, gescholden en geslagen. Volgens inlandsch oordeel is van zoodanig geval, door het plegen van bedrog of het spreken van onwaarheid, de vrouw zelve de oorzaak.

\section{Geboorte.}

Bij geboorte van een kind wordt hetzelve den voornaam gegeven naar den dag der week, benevens voor het eerste kind den naam des grootvaders van vaderszijde; voor het tweede kind (een jongen) den naam van een der broeders of zusters des grootvaders van vaders. zijde; voor een meisje den naam der grootmoeder van vaderszijde. en voor het derde eenen naam der familie mede van vaderszijde. 
De geboorte van twee kinderen één van het mannelijk en één van het vrouwelijk geslacht wordt voor gelukkig gehouden; van drie kinderen twee van het vrouwelijk en een van het mannelijk, voor ongelukkig.

Tweelingen van het mannelijk geslacht worden genaamd: Attc Pennien en Atta Kakkera; te Elmina en voor zooverre zich de Fantijnsche taal aan de benedenkust uitstrekt, blijven deze namen voor meisjes hetzelfde. Aan de bovenkust voegt men er bij Attanza. terwijl te Accra mannelijke tweelingen Accoté en Accoêtte, en vrouwelijke Accolé en Akwako genoemd werden.

Bij de geboorte van drie zonen achter elkander is de naam van de derde steeds Mijzang en voor een meisje Manza. Van zes kinderen is de naam voor het zesde Essian, het zevende Esson, het achtste Ö̈tju, het negende Akon, het tiende Badoa en het elfde Doekoe.

Acht dagen na de geboorte wordt het kind een stukje fetich goud en allerlei fetiche touwtjes etc. om den hals gehangen, ten eincle het voor ziekte en andere ongelukken te bewaren.

Bij eene gelukkige geboorte wordt vrij algemeen een schaap, kippen of boschkabriet aan de bijzondere fetiche geofferd; te Elmina wordt bij deze gelegenheid een schaap of kabriet gedood, en een gedeelte daarvan aan ieder lid en familie als geschenk gezonden.

Bij eene ongelukkige geboorte brengt de vrouwsfamilie eene kabriet welke wordt geslacht, en het bloed met zee- en zoetwater vermengd en daarmede vrouw, kind en huis besprengd. Dit gebruik is niet algemeen en kan worden aangenomen als alleen te Akim en meer bovenwaarts de kust, bestaande.

De derde der achter elkander geboren zoons, genaamd Mijzang worden eenige kakkeraadjes of stukjes fetiche goud en eenige koralen, Man genaamd, om de regterhand gebonden. Aan de bovenkust mag hij jongeling geworden zijnde, met dezelfs vader geene nieuwe rijst in eene pot gekookt eten, en moet dezelve voor zich in eene afzonderlijke pot en vuur laten bereiden.

Een jongeling wordt als meerderjarig of als man beschouwd zoodra hij vader of gecalisiaard is, eene jonge dochter wanneer zij hare maandstonden heeft bekomen.

Het is misschien niet ongepast om hier van een gebruik te gewagen wat uitsluitend te Accra plaats heeft. Alle jaren in de maand Februarij (Harmattaan-tijd) worden de jongens van zeven à acht jaren oud aldaar besneden; en wie zijne kinderen aan deze 
gewoonte zoude willen onttrekken, stelt zich aan de algemeene verachting, en hen aan de grootste mishandelingen bloot. Kinderen die de besnijding ondergaan hebben dragen gedurende acht dagen geene andere kleeding, ,als eene mat" die hen geheel omhuld en met een fetiche touwtje om den hals wordt gehangen. Wáár of bij wie zij zich in deze kleeding vertoonen worden hun kleinigheden ten geschenke gegeven.

\section{Gebruiken bij den Dood en de Begraving.}

De gebruiken welke bij het afsterven en ter aarde bestellen plaats hebben zijn zeer verschillend; de fetiche plegtigheden in de boschkrommen en vooral in het Ahantasche landschap veelvuldig.

Bij sterfgeval wordt in den regel naar den stand der personen voor de familie costuum gemaakt; was de overledene een vermogend man of een kromsgroote dan geschiedt het costuum maken mede door de kwartieren, en dikwijls door de bewoners van naburige krommen. Veelal wordt slechts eenen dag costuum gemaakt en onder het drinken van rum en palmwijn veel buskruid verschoten; men komt echter acht dagen iedere morgen ten sterfhuize bijeen, bepaaldelijk om familiezaken te vereffenen en te regelen.

Den eersten dag na het overlijden wordt er door de familie en vrienden van den ontslapene wat goud, paantjes, palmwijn of rum aan deszelfs opvolger gegeven, en hieruit de onkosten van het costuum goed gemaakt; het overblijvende onder de familie van moederszijde verdeeld of ontbrekende door hun gekweten.

Bij overlijden van iemand die veel goud nalaat, wordt er van dit bij het lijk ten toon gesteld, de hals, handen en voeten met fetiche goud versierd, en een gedeelte met den overledene begraven.

De lijken worden gewasschen, gekist en in hun eigen of familiehuis begraven; kinderen of slaven waarvoor slechts weinig of geen costuum wordt gemaakt, in hunne paantjes, vóór, somtijds in het huis hunner ouders of meesters. Jongelieden worden gekist, echter ook vóór de woning of in het voorhuis van hunne ouders of naastbestaanden begraven.

Op den dag van overlijden wordt door den opvolger van den overledene aan het kwartier waartoe deze behoorde kruid en drank gezonden; hetzelve trekt daarna met de kwartiervlag naar het sterfhuis om eenige geweerschoten te doen. Voor eene vrouw wordt zulks ook gedaan wanneer zij „Groote vrouw of vaandrige” bij het kwartier was.

D1. 88. 
Bij overlijden van een Negerhoofd moet derzelver familie of opvolger kruid zenden bij elk der kwartieren van het krom, en de kwartieren zijn verpligt dit gezamentlijk ieder onder zijne vlag ten sterfhuize te komen verschieten.

Ingeval van toevallige dood of zelfmoord wordt er geen costuum gemaakt, de overledene buiten het krom begraven, het lijk met aarde besmeerd en tot de ter aardebestelling opentlijk ten toon gesteld.

Er hebben gevallen plaats dat bij het afsterven de familie door bijzondere omstandigheden verhinderd wordt het gewoon costuum te maken, dikwijls wordt alsdan eerst jaren daarna voor de afstammelingen aan die verpligting voldaan.

$\mathrm{Na}$ den afloop van een dood-costuum gaat de familie bij de vrienden en allen die hetzelve hebben bijgewoond hunnen dank betuigen; de rouw wordt met bekendmaking daarvan een jaar na het overlijden afgelegen, als wanneer zij zich buiten het krom in een stroomend water gaan reinigen, en in het wit gekleed terugkomen. Ter gedachtenis aan den overledene worden er jaarlijksch slagt- en dankoffers door de familie op het graf gebragt.

\section{Erfregt en Opvolging op de Stoel.}

Kinderen erven niet van den vader maar wel van de moeder. Erfgenamen van den man worden zusters kinderen, en verder al wat regtstreeks uit de moederlijke linie spruit. De neef erfgenaam van den. oom of de oom erfgenaam van den neef wordende, erven deze tegelijkertijd zijne vrouwen, en worden dezelve van dat tijdstip af als zijne eigenen beschouwd, en is het voor hen betaalde calisaar costuum etc. ingeval van scheiding door hem te vorderen. Geene wettige erfgenamen bestaande wordt de oudste slaaf erfgenaam van de stoel en goederen; slaven en impia's gaan met de erfenis over.

De opvolging op de stoel geschiedt gewoonlijk door den wettigen mannelijken erfgenaam; goud en goederen aan de stoel verbonden kunnen door den erfgenaam niet willekeurig worden gebruikt en gaan met elken opvolger over.

Het koning- en makelaarschap volgt zich in de familie op. Bij overlijden van een kromshoofd wordt een van de oudste prinsen door de kromsregering gekozen, en aan de gezamentlijke kwartieren vöorgesteld.

Aangenomen zijnde wordt het nieuw benoemde hoofd onder schieten en schreeuwen het krom rondgedragen, en voorafgegaan van zijne Caboceers stoel. De vaandrigs worden voor de kwartieren 
gekozen, en volgen zich meestal van den vader op den oudsten zoon op.

\section{Echtscheiding.}

Echtscheiding kan plaats hebben met of zonder terugbetaling van het calisaar costuum. Wettige redenen voor het eerste geval zijn: overspel der vrouw of ander bewezen wangedrag. Voor het tweede geval geeft redenen: bewezen mishandelingen van den man, of vrije wil van dezen om van de verbintenis ontslagen te zijn. Bij de scheiding heeft gewoonlijk een schikking of verdeeling der kinderen plaats.

Is het de volstrekte wil der moeder om alle hare kinderen bij zich te behouden, of de familie der vrouw eischt dezelven, dan wordt wanneer de hoofddrank bestaande in twee gallon rum (hetwelk hiervoor bepaaldelijk bij het calisaar costuum wordt gevoegd) niet is betaald, de vader voor elk kind de waarde van drie Engels goud aan buskruid, een stuk paantje en een half Engels goud voldaan. Is door hem de hoofddrank verstrekt dan staat hij het regt op zijne kinderen af tegen betaling van negen Engels goud voor elk mannelijk en acht Engels voor ieder vrouwelijk kind.

\section{Echtbreuk.}

In het huwelijk is het voor een man geen misdrijf gemeenschap te hebben met eene vreemde vrouw, en strekt het evenmin het meisje tot schande of verwijt, vóor het huwelijk kinderen of gemeenschap met eenen man te hebben gehad.

Eene gecalisaarde vrouw zich met eenen anderen man afgegeven hebbende, is verpligt dit te belijden opdat haar man het hiervoor gestelde costuum eische. Klaagt iemand een ander voor overspel aan en verliest hij het geschil dan is hij verpligt het bedoelde costuum aan den ten onregte beschuldigde te voldoen, en brengt in een zoodanig geval met voorkennis der vrouwsfamilie het betaalde bedrag bij dat van het voor de vrouw betaalde hoofdgeld.

Wanneer de vrouw overspel pleegt en dit voor den man geheim houdt, wordt haar wanneer later ziekten of ongelukken onder hare kinderen voorkomen, zulks ten laste gelegen, en is zij genoodzaakt fetiche te drinken, om zich van het misdrijf van èchtbreuk te zuiveren.

De costumen wegens overspel verschillen in grootte naar gegoedheid en stand van de personen met wie de vrouwen zijn gecalisaard.

Zooals reeds vroeger is gezegd; eene vrouw door haren man als 
impia gesteld, en in deze betrekking hem ontrouw zijnde, kan hij daarvoor geen costuum eischen. De vrouw brengt bij teruggave der geleende som, alle de in overspel verwekte kinderen bij haren man, welke deze als de zijnen kan beschouwen en over hen naar welgevallen beschikt.

Ingeval van bloedschande, wat zelden voorkomt, zijn de daders aan de algemeene verachting prijs gegeven; worden weggejaagd of door hunne naastbestaanden niet meer erkend, somtijds zelfs als slaven verkocht. Hij die zich aan deze misdaad schuldig maakt en op de plaats van het voorval verblijft is uit ieders huis gebannen, en slechts met eene gecalisaarde vrouw sprekende, wordt van hem costuum voor overspel gevorderd. Kinderen in bloedschande verwekt, worden met de moeder verbannen en krijgen den bijnaam van kind der schande: Enietoe-ba.

\section{Diefstal.}

Kleine misdaden van deze aard door de kroms grooten afgemaakt wordende, vervalt de dader in eene kleine boete, wordt aan het blok geslagen of ook wel met rietslagen gestraft. Geene genoegzame bewijzen van de misdaad aanwezig zijnde, wordt er toevlugt genomen tot den fetichen priester, welke de dader ,ter regt of onregt" door het touwtje trekken of Edoemdrinken aanwijst.

Bij diefstal van goud of goederen van waarde wordt dikwijls de hoeveelheid van het gestolene zeer vergroot, en daar de dief meestal slechts gestraft wordt, met teruggave van het ontvreemde en eene betrekkelijke boete, loopt hij die hem behulpzaam is, het gestolene verbergt, bewaart of koopt, ook geen ander gevaar als ook hij de helft der door de palabber ontstane onkosten betaald.

Voor het stelen van vee en veld-vruchten bestaan de volgende straffen. Wie een ram steelt betaalt de waarde in ligt goud, of geeft hetzelve terug met $11 / 2$ Engels goud en een flesch rum. Voor één schaap, twee schapen $1 \frac{1}{2}$ Engels goud, en een flesch rum. Voor kabrieten en varkens hetzelfde; kippen, eenden, en andere kleinigheden teruggave of betaling in goud volgens marktprijs.

Wie zich schuldig maakt aan het stelen van veld-vruchten wordt gestraft met betaling van $11 / 2$ Engels liquide goud en een flesch rum. Hem wordt van het gestolene om den hals gehangen, en nadat hij met houtskolen en water is geverwd, aan een touw door het krom rondgeleid en uitgejouwd. 


\section{Verwonding.}

$\mathrm{Hij}$, die een ander moedwillig verwondt, is verplicht de onkosten van doctor en medicijnen te voldoen, en den verwonde schadeloos te stellen voor deszelfs verloren tijd.

Beleediging of mishandeling wordt door het schenken van rum geschikt en afgedronken. Hij die van twee vechtende negers voor een derzelve partij trekt en hem helpt, wordt gestraft met eene dollar boete en eene flesch rum ten behoeve van de tegenpartij.

\section{Moord.}

De manslag zonder opzet, bij ongeluk of onvoorzigtigheid, op de jagt of anderzints begaan, mits wordende beleden en dadelijke hulp toegebragt, wordt slechts gestraft met betaling aan de familie van den overledene van een once acht Engels goud, twee vadems wit baft een anker rum en verschaffing der doodkist.

Moord met voorbedachte rade, verraderlijk of met moedwil begaan wordt gestraft met betaling van zes oncen liquide goud aan de familie van den vermoorde. De moordenaar of deszelfs familie zendt in het onderhavige geval veertien Engels goud aan de naastbestaande van den verslagene met verzoek deze te willen aannemen, en bijeen te komen om de zaak te schikken. Beide familien aan het verzoek voldaan hebbende, wordt onder het drinken van rum en palmwijn de kwestie behandeld, en is dezelve geschikt dan voldoet de moordenaar zes oncen goud en twee schapen terwijl de kosten van rum etc voor zijne rekening zijn. $\mathrm{Zij}$ geven elkander de verzekering de zaak is afgemaakt, en voor dezelve nimmer iemand mag bemoeijelijkt worden. Regent het onder de behandeling eener dusdanige zaak dan staat ieder op en begeeft zich huiswaarts zeggende: de vermoorde weent, eene omstandigheid waardoor de moordenaar verpligt is een schaap aan de familie van den vermoorde te zenden en genade te vragen.

Het zal wel geen betoog behoeven dat op het Nederlandsche grondgebied zelden moord wordt gepleegd, zonder dat het Gouvernement er kennis van bekomt; de misdadiger wordt als dan volgens de Hollandsche wet gestraft, of onttrekt zich aan dezelve door zich onmiddelijk na het plegen der manslag het leven te benemen, hetgeen dikwijls geschiedt bij onvermogende of dezulken die berekenen kunnen voor Europeanen teregt te zullen staan. 


\section{Het geven van Dasje van zichzelve of anderen.}

Op twee wijzen geschiedt zulks, of iemand geeft zichzelven voor dasje (geschenk) aan bijzondere personen, aan de fetiche of aan het kwartier, of eene tweede persoon wordt voor schulden of andere oorzaken aan het kwartier voor dasje gegeven. Moeijelijk is het voor den Neger om slaven die zich wel bijzonder aan de fetiche voor dasje geven, van den priester uitgeleverd te krijgen, omdat deze dusdanige personen van dat oogenblik af als hun eigendom beschouwen. Wordt door den eigenaar eene klagte bij het gouvernement ingeleverd, dan geschiedt de uitlevering tegen betaling van $4 \frac{1}{2}$ Engels goud.

Iemand zich aan deszelfs kwartier voor dasje gegeven hebbende laat hetzelve zich wanneer de familie reclameert met eene vergoeding te vreden stellen.

Wanneer iemand voor schulden een vreemd persoon aan het kwartier voor dasje geeft, wordt deze persoon door hetzelve opgeroepen, de zaak onderzocht en de voor dash ontvangene weder in vrijheid gesteld, of veroordeeld tot de betaling van schuld en onkosten. Zeer regtvaardig wordt hierin niet gehandeld, en hij die het grootste geschenk geeft, is zeker de palabber te winnen.

\section{Panjaren.}

Even als het geven voor dasje heeft dit mede op twee wijzen plaats : namentlijk er worden personen of goederen voor anderen genomen of gepanjaard.

Het panjaren van personen heeft plaats voor schulden of andere omstandigheden. Wanneer iemand van een persoon op een verwijderd krom verblijf houdende, geld te vorderen heeft en de betaling niet kan erlangen, neemt hij wanneer een lid der familie, of ook wel slechts een bewoner van het krom van zijnen debiteur onder zijn bereik komt, dezen gevangen tot zoolang de betaling volgt, waartoe de schuldenaar al zeer spoedig door de naastbestaanden van den gepanjaarde wordt genoodzaakt.

Onderlinge twist tusschen verschillende krommen bestaande wordt van weerszijde zonder onderscheid van personen gepanjaard. Het panjaren van goederen geschiedt bijna uitsluitend voor schulden, en heeft evenals bij de panjaring van personen dan plaats, wanneer de betaling voor vroeger geleverde goederen wordt geweigerd. De crediteur begeeft zich' in zoodanig geval bij dezen of geenen koopman en neemt, met het leggen van eene bezwering op het hoofd van zijnen 
debiteur, zoovele goederen als zijne vordering bedraagt. Wil de schuldenaar dan niet in eene groote palabber of in onkosten vervallen, is hij genoodzaakt het op zijne rekening gepanjaarde te voldoen, tenzij hij door aanklagte bij het Gouvernement regt zoekt.

\section{Feesten. Jams - Costuum.}

$\mathrm{Na}$ den regentijd in de maanden Junij, Julij of Augustus vieren zij het jams costuum, zeggende de fetiche het land met regen heeft gezegend, en zij hem daarvoor van het nieuwe product ten offer moeten brengen. De fetiche priester van Benjan is de man die zich te Elmina voor drie weken in het fetiche hok opsluit; gedurende dien tijd mogen de negers in genoemde rivier niet visschen, geene geweerschoten doen, geene trom slaan, geen dood costuum maken en 's avonds niet op straat zingen.

Met het einde van de derde week laat bedoelde priester de nacht bij hem aan het fetiche hok doorbrengen met zingen en dansen. Den volgenden morgen gaat hij uit, vergezeld van zijne zangers en trommelslagers langs de straat dansende, en denzelfden dag 's avonds wordt de rivier geopend, waarna kwartier één van Elmina met het jams-costuum begint.

\section{Scheld en slaan Costuum.}

Van dit gebruik, wat slechts te Elmina bestaat, is alleen te zeggen dat de inlander zich verbeeldt er een afgod met name Enzan is, op wiens last jaarlijks de vrouwen door de mannen moeten worden gescholden en dat daardoor de vrouwen op last van de godin Iadodo het regt hebben, om eene week na de opening der rivier de mannen te slaan, die deze last op hun uitoefenden.

\section{Tijger en Buffelfeest.}

Dit feest, thans bijna onbekend, was in vroegere jaren de grootste vereering welke een Caboceer aan zijne vrouw konde doen, nadat hij haar van allerhande soorten van paantjes, gouden lijfsieraden, slaven en slavinnen had voorzien. Bij gelegenheid dat er een tijger of buffel werd geschoten, kocht hij dezelve en vereerde daarmede zijne oudste vrouw. Het dier werd tot aan de woning der vrouw gedragen door lijfeigenen, en vergezeld door de naastbestaanden des Caboceers en die van zijne vrouw, ieder eene groene tak in de hand dragende. Poten, kop en staart werden daarna gedroogd en zorgvuldig bewaart tot het jams-costuum als wanneer de vrouw een houten altaar liet maken, 
bedoelde deelen liggende op groene bladen ten toon stelde, en daarvoor slagt en drankoffers bragt.

\section{Kontoem.}

Het kontoem of nieuw-jaarsfeest, sedert jaren in Elmina verboden en in het Ahantasche landschap het eenigste jaarlijksche feest, valt gewoonlijk in tegen het laatst van Augustus of begin van September, duurt acht dagen en moet een begin nemen op den goeden Adei (Zondag). Het bestaat alleen uit eene fetiche dans welke gedurende vier dagen door de verzamelde en van alle zijden toegestroomde menigte op het slaan der groote kontoemtrom worden uitgevoerd, en waarbij de vrouwen met hunne beste paantjes en sieraden, de mannen en kinderen op de zonderlingste wijze zijn opgeschikt.

$\mathrm{Na}$ den afloop van deze dans ter eere van Affaatju, de fetiche der kontoem, begint de Ampan of tweede fetiche dans, welke alleen door vrouwen wordt uitgevoerd, en waarmede de achtste dag wordt bereikt. Bij het eindigen der kontoem neemt ieder een stukje brandend hout en werpt dit in zee onder de uitroep van: Affaatju neem $U w$ hout en vuur terug.

Gedurende de kontoem is het straffeloos toegestaan die zangen te zingen, welke door de jonge negers van het krom in de laatste drie weken vervaardigd zijn, en welke meestal handelen over slechte vrouwen, gepleegde diefstal en soortgelijke voorvallen in het krom.

Ter aanleering van het slaan der kontoemtrom en vervaardigen der bedoelde zangen, vereenigen zich de jonge lieden buiten het krom, en vrouwen, kinderen, noch vreemdelingen worden in deze vergaderingen toegelaten.

In ieder huisgezin worden met de kontoem alle oude kookpotten etc vernietigd en vrouwen, kinderen, impia's en slaven van nieuwe paantjes voorzien.

Daar waar een Europeaan bevel voert wordt de kontoem in het fort gedanst, en van ouds bij die gelegenheid de verzamelde menigte op rum en tabak onthaald.

\section{Doodschieten van een Pattekoe.}

Wanneer iemand een pattekoe heeft gedood moet hij daarvan dadelijk aan de kromregering kennis geven, en wordt het dier op kosten van den jager naar de vergaderplaats gebragt, en hetzelve twee verdedigers gegeven. Is de jager in staat de door deze geopperde bezwaren te wederleggen, dan wordt hij ten bewijze van regt met kalk 
of witte aarde besmeerd, en onder het schieten met geweren rondgeleid; de pattekoe wordt meestal, na met fijn gemaakte houtskolen te zijn bespreid, rondgedragen en verbrand. Een zoodanig proces kost den jager eene goede hoeveelheid rum.

Aldus opgemaakt binnen het Hoofd-Kasteel St. George d'Elmina 20 Mei 1851.

De Lt. Kolonel, Gouverneur ter Kuste van Guinea :

A. VAN DER EB. 